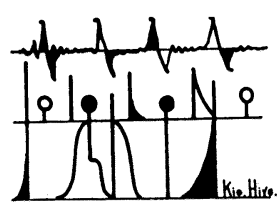

1. 緒言

高塭冶金プロ七スにおいては多くの相が関係し，それ ら各相間に種々な反応が進行している，これらの反応は いずれも不均一反応であり, 各相界面をとおって進行す るため, 反応の進行には界面の性質が大きな役割をはた している.さらに高温冶金プロセスに打ける様々な界面 現象を検討する上にも界面性質に関する深い知識が必要 である。しかし界面の性質は各相バルクの性質にくらべ て研究が十分に進んでいないので反応や界面現象を定量 的に論じるには問題が多い.

溶融金属(以下メタルと称す)は製錬過程において溶融 スラグ(以下スラグと称す) と接触して存在する機会が多 く,メタルースラグ界面の性質のはたす役割は灯内反応 だけでなく炉外におけるスラグ，フラックスによる処理 のプロセスにとっても重要な問題である.ささらにスラグ はイオン性の溶液であることからメタルとの界面におい ては界面電気現象が存在することが種々な研究から認め られている.そのためメタルースラグ反応を電気化学的 に取扱ら試みがなされつつあるが，界面における現象へ のアプローチが現象論的段階を十分に抜けきっていない 現在, 界面に対する電気化学的知識の集積が切望され る.

現在, 高温に拈けるメタルースラグ界面の電気化学的 知識一電気毛管性, 表面電荷密度, 界面電気二重層な どーは実験技術の困難さから未だに少なく得られた結果 にも問題点が多くみられ，十分に統一した結果が得られ ていない，そのためここには現在主としてソ連において 得られているメタルースラグ界面の電気化学的性質につ いてまとめ，それらを基にして界面現象について若干の 説明を加えたい．

\section{2. メタルースラグ間における界面電気現象}

水銀と電解質水溶液が接触すると両相の電位差が界面 にあらわれる.これに対応して界面に接する電解液中の イオンの分布や配向に変化を生じ, 界面電気二重層が形

\footnotetext{
* 大阪大学教授; 工学部治金学科

** 大阪大学; 工学部冶金学科
}

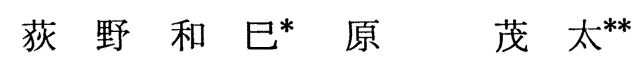

成される.この界面電気二重層の考方方は古く 1879 年 に Helmholtzによって示された，この電気二重層の存 在のために種々な界面電気現象が生じるといわれる.

界面電気現象は Lippmann が 1875 年に見出した電気 毛管性のように従来水銀之電解質水溶液系に打いて多く の人々によって研究されてきた. その結果, 水銀一電解 質水溶液界面に関する多くの知識が得られている。 スラ グもイオン性溶液であるため, 高温においてメタルと接 触する場合, 接触界面に扎いて界面電気現象の存在が当 然予想される。

このメタルースラグ系の界面電気現象に対する最初の 試みは 1952 年の Esin ら ${ }^{(1)}$ にるる高温に打故電気毛管 現象の論文であろう。それ以来, 主としてソ連の研究者 によって高温のメタルースラグ界面に打忛る電気現象に 対し精力的研究が行なわれ現象論的研究からさらにその 実体へのアプローチが発展しつつある. 最近ではメタ ルースラグ反応の電気化学的取扱いの発展と共に我国に おいても固体および液体金属 - スラグ界面における界面 電気現象に関する研究も進みつつあり今後の発展が期待 される段階に到達している.

\section{(1) 電気毛管現象}

電気毛管現象はイオン溶液中にある電極の表面張力 (溶液との界面張力)が電極電位によって变化する現象で あって, Lippmannによって発見されて以来, 電極現 象, 電気二重層の構造の研究のために重要な現象として 広く研究がなされている。

従来この分野の研究は主に水銀一電解質水溶液系であ って, これら両相間の電位と界面張力との関係は第 1 図 に示すように 2 次曲線で示される. この曲線を電気毛管 曲線 (electro-capillary curve) といい, この曲線の形状 より種々な界面性質に関する知識が得られる.電気毛管 曲線において界面張力が極大になっている点を電気毛管 極大点(electro-capillary maximum-e.c.m.) といい, その点の電位を $E_{\mathrm{ecm}}$ で示される.この曲線の形状は界 面に吸着する物質の種類によって変化するが, このこと

(1) O. A. Esin, Yu. P. Nikitin and S. I. Popel : Doklad.Akad.Nauk.SSSR, 82 (1952), No.3, 431. 


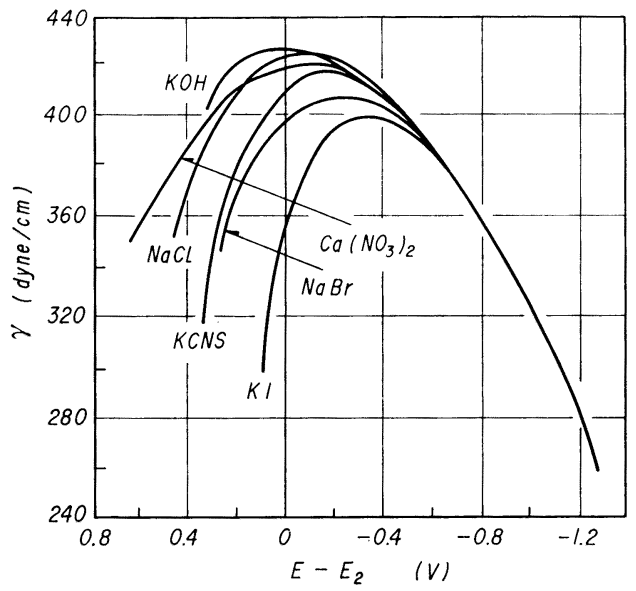

第 1 図 種々な電解質溶液中における $\mathrm{Hg}$ の 電気毛管曲線 $\left(18^{\circ} \mathrm{C}\right)$

から逆に曲線の形状より吸着物質を判断することもでき る.

水銀一電解質水溶液系にくらべて高温に打けるメタルー イオン融体系の電気毛管現象に関する研究ははるかに少 ない.メタルー溶融塩系における電気毛管曲線の研究は 1936 年の Karpachevら (2)による capillary-electrometer を用いた研究をから始まっている.この研究は第 2 図に 示す capillary electrometer によって $\mathrm{Pb}, \mathrm{Cd}, \mathrm{Bi}, \mathrm{Tl}$ な ぞのメタルあるいは合金と $\mathrm{LiCl}+\mathrm{KCl}$ 系融体とについて $450^{\circ} \mathrm{C}$ においてなされたものであり，第3 図に示すよう に得られた電気毛管曲線はほぼ 2 次曲線とみなされる。 この結果では $E_{\mathrm{ecm}} \gamma_{\mathrm{ecm}}$ はメタル, 塩の種類によって変 化するのが観察される. 図の $\mathrm{LiCl}+\mathrm{KCl}$ 共晶塩とメタ ル系の $E_{\mathrm{ecm}}$ はメタルのイオン半径の順に負電位側に移 動し $\gamma_{\mathrm{ecm}}$ もその順に低下寸る傾向がみられる. $\mathrm{Pb}$ に対 し塩中に $\mathrm{KI}$ を加えた場合には $E_{\mathrm{ecm}}$ は変化せず $\gamma_{\mathrm{ecm}}$ の み低下している。 これは I' イオンが $\mathrm{Cl}^{-}$イオンよりも

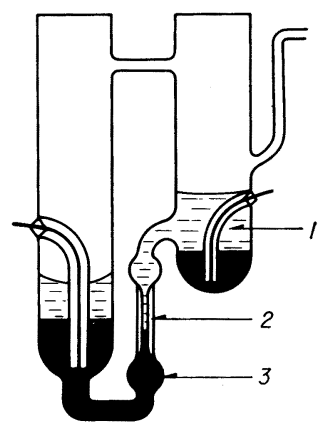

第 2 図 capillary electrometer(2) 1. 溶融塩, 2. 毛管, 3. メタル

(2) S.V.Karpachev and A.G.Stromberg : Zhur. Fiz. Khim, 10(1936), No.7, 754. A.I.Beliaev: Fizicheskaia Khimiia Rasplavlennykh Solei, Metallurgizdat, (1957), 237.

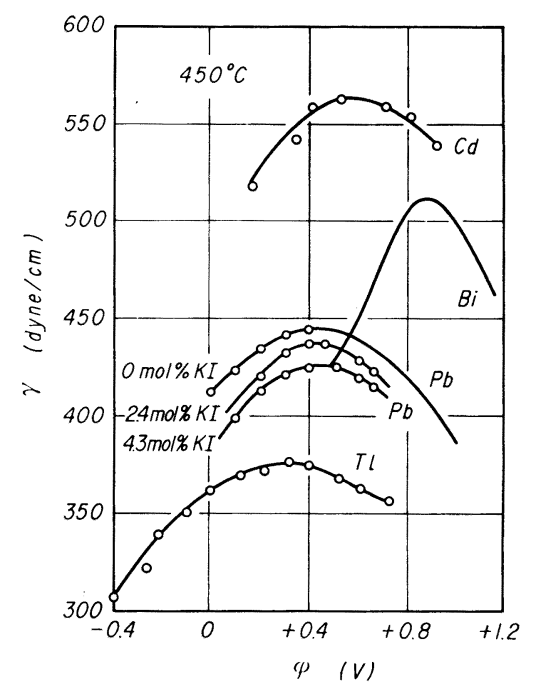

第 3 図種々な溶融金属と溶融 $\mathrm{LiCl}-\mathrm{KCl}$ との 電気毛管曲線 ${ }^{(2)}$

$\mathrm{Li}^{+}, \mathrm{K}^{+}$イオンによってより強く分極されているためと 考えられている. このよらにメタル－溶融塩系において 明瞭な電気毛管曲線の存在が確認された。メタルー溶融 塩系は比較的温度も低く測定装置の製作，測定も容易で あるが，メタルースラグ系のように $1200 \sim 1300^{\circ} \mathrm{C}$ 以上 の高温においてて測定技術上困難がきわめて多く，精度 の良い結果は得にくいとみられる.

メタルースラグ系における電気毛管曲線はフルムキン の指導のもとに Esin, Nikitin, Popel(1)が 1952 年におこ なった研究が最初と思われる.この場合, 電気毛管曲線 は capillary-electrometer ではなく第 4 図に示す装置に よってX線透視法で静滴の形状を観察し，電位による界 面張力の変化から第 5 図に示寸電気毛管曲線を得てい る. この方法はメタル静滴を用いて界面張力を算出する ため，静滴をあまり小さくできない，その大きさは直径 14〜16 mm, 表面積 3.5 $4 \mathrm{~cm}^{2}$ であり，この対極であ る黒鉛はそれに比して十分に大きくとってあるため分極 はメダルースラグ面のみで起るとされている．しかし第 5 図の測定結果からもわかるよらに, この系では前述の 水溶液, 溶融塩にみられるよらな電気毛管極大点がみら

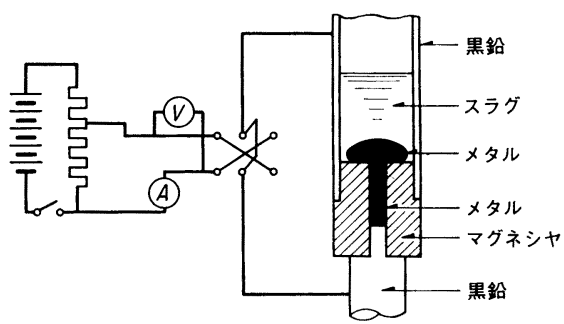

第4 図メタルースラグ界面に扑㚈電気毛管 曲線測定装置 ${ }^{(1)}$ 


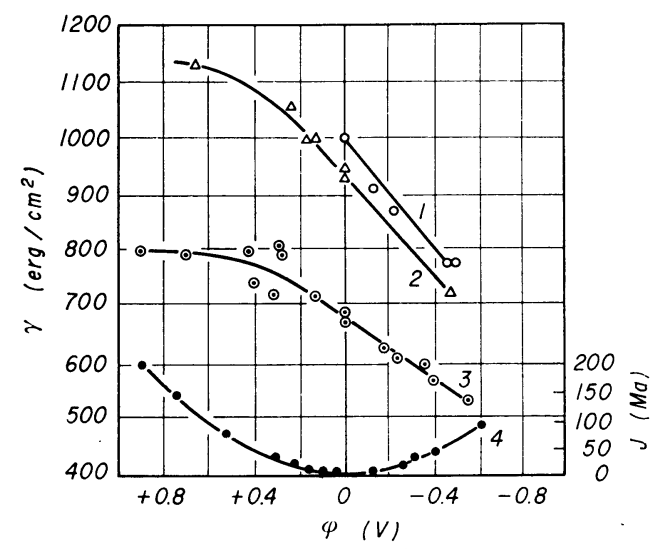

第 5 図 溶融スラグ中の $\mathrm{Fe}-\mathrm{C}$ 合金の電気毛管 曲線 ${ }^{(1)}$

スラグ- $\mathrm{CaO} 8.3 \%, \quad \mathrm{Al}_{2} \mathrm{O}_{3} 5.6 \%$, $\mathrm{SiO}_{2} 71.5 \%, \quad \mathrm{Na}_{2} \mathrm{O} 14.6 \%$

$\mathrm{Fe}-\mathrm{C}$ 合金 $1: 2.5 \%, 2: 3.0 \%, 3: 4.0 \%$

れない。この点に関して Patrov ${ }^{(3)}$ は静滴の表面積が大 きく, かつ高電流密度では電流分布の悪いことを指摘し ている.

Esin らの研究は $71.5 \% \mathrm{SiO}_{2}, 14.6 \% \mathrm{Na}_{2} \mathrm{O}, 8.3 \%$ $\mathrm{CaO}, 5.6 \% \mathrm{Al}_{2} \mathrm{O}_{3}$ 系スラグと $\mathrm{Fe}-\mathrm{C}$ 合金 $(\mathrm{C}=2.5,3,4 \%)$ とについて求められている. 電気毛管曲線の形状から陰 分極によって界面張力は低下しているが，陽分極では界 面張力の変化は少なく, さらに $\mathrm{SiO}_{2}$ の添加より $\mathrm{Na}_{2} \mathrm{O}$ の添加の方が界面張力を強く低下させる. これらのこと より Esin らはメタル面が負に帯電していると考えてい る. Esin らのこの研究はメタルースラグ系において界 面電気現象研究の分野を用いたものとしての意義は大き W.

この Esin らの研究の欠点を克服するため Patrov ${ }^{(3)}$ (1959 年は毛管圧力法を考案しメタルースラグ系の電気 毛管現象の研究をおこなった。この方法は毛管内におい てメタルースラグ接触界面を作るためE Sin らの静滴法 にくらべてメタルースラグ界面積をはるかに小さくでき る利点を有している．測定は第6 図に示寸装置において 先端に毛管 (半径 $r$ )を有する耐火管内の最大圧力 $P$ を求 め

$$
\gamma_{\mathrm{m} \cdot \mathrm{s}}=P \cdot \frac{r}{2}
$$

の関係より界面張力 $\gamma_{\mathrm{m} \cdot \mathrm{s}}$ を得るものである. このよう にして得られた $\mathrm{Fe}-\mathrm{C}$ 合金と $\mathrm{CaO}-\mathrm{SiO}_{2}-\mathrm{Al}_{2} \mathrm{O}_{3}$ 系スラグ の電気毛管曲線を第7図に示す. 図からあきらかなよう に毛管曲線は水溶液, 溶融塩と同様に明暸な電気毛管極 大点を有する 2 次曲線を示している. このことからメタ ルースラグ系においても明暸な 2 次曲線状の電気毛管曲

( 3 ) B.V.Patrov : Izvest. VUZ. Chern. Met., (1959), No. 6,3 .

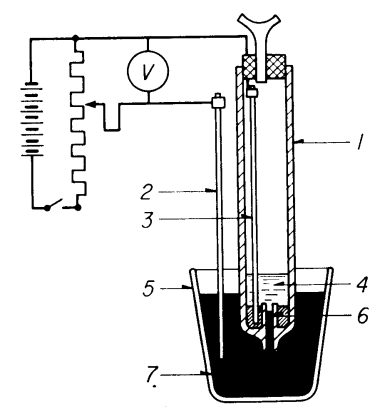

第 6 図 毛管圧力法による電気毛管曲線測定装置 ${ }^{(3)}$

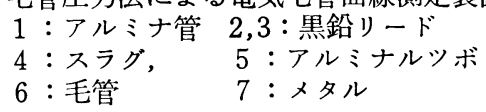

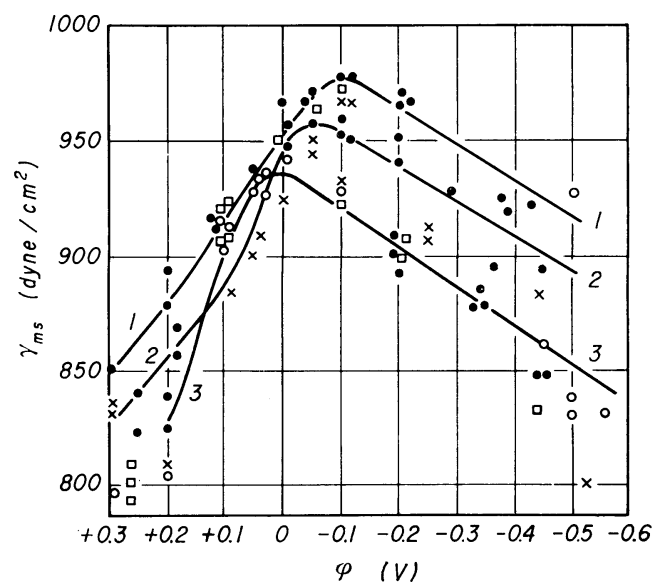

第 7 図 溶銑と $\mathrm{CaO}-\mathrm{SiO}_{2}-\mathrm{Al}_{2} \mathrm{O}_{3}$ スラグ間の電気毛 管曲線 $\left(1420 \sim 1480^{\circ} \mathrm{C}\right)^{(3)}$

1: $41.8 \mathrm{~mol} \% \mathrm{CaO} \quad 2: 43.9 \mathrm{~mol} \% \mathrm{CaO}$

$3: 50.3 \mathrm{~mol} \% \mathrm{CaO}$ $\frac{\mathrm{mol} \% \mathrm{SiO}_{2}}{\mathrm{~mol}_{0} \mathrm{Al}_{2} \mathrm{O}_{3}}=3.9$

線を得ることが認められた．この場合，第 7 罒に示すよ らに $\mathrm{CaO}$ の増加と共に $E_{\mathrm{ecm}}$ は正電荷の方に移行し, $\gamma_{\mathrm{ecm}}$ も減少している.このことはスラグ側の界面に $\mathrm{Ca}^{2+}$ が吸着していることを示している.ささらに $\mathrm{CaO}$ を一定 として $\mathrm{SiO}_{2}$ と $\mathrm{Al}_{2} \mathrm{O}_{3}$ の割合をかえた場合には第8 図の ように $E_{\mathrm{ecm}}$ は shift しない.このことはスラグ側の吸 着物質が $\mathrm{Ca}^{2+}, \mathrm{Fe}^{2+}, \mathrm{Mn}^{2+}$ であるから, アニオンの種 類が変っても $E_{\mathrm{ecm}}$ には影響がないのであろら．

このように静滴法, 最大圧力法によってメタルースラ グ系において電気毛管曲線が得られたが，これ以後この 分野の研究はソ連において種々な系について活発に抗こ なわれている. その電気毛管曲線の二, 三の例を第 9 図 にまとめて示す. 第 9 図(a)は $\mathrm{Cu}$ と $40 \mathrm{CaO}, 40 \mathrm{SiO}_{2}$, $20 \mathrm{Al}_{2} \mathrm{O}_{3}, 55 \mathrm{CaO}, 45 \mathrm{Al}_{2} \mathrm{O}_{3}$ 系との電気毛管曲線でこの場 合, スラグの組成によって形状がことなっている(4). 第

(4) A.A.Deriabin,S.I.Popel and O.A.Esin: Izvest. VUZ.Tsvet.Met., (1965), No.2, 32. 


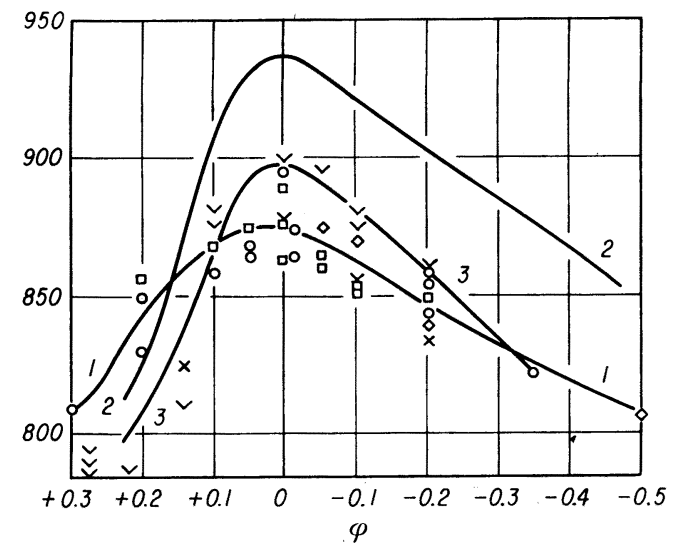

第 8 図 溶銑と $\mathrm{CaO}-\mathrm{SiO}_{2}-\mathrm{Al}_{2} \mathrm{O}_{3}$ 系スラグ間の 界面電気毛管曲線 (3)

$1: 48.4 \mathrm{CaO}, 46.2 \mathrm{SiO}_{2} \quad 5.3 \mathrm{Al}_{2} \mathrm{O}_{3}$

$2: 50.3 \mathrm{CaO}, 38.6 \mathrm{SiO}_{2} 11.1 \mathrm{Al}_{2} \mathrm{O}_{3}$

$3: 49.3 \mathrm{CaO}, 43.5 \mathrm{SiO}_{2} \quad 7.2 \mathrm{Al}_{2} \mathrm{O}_{3}$ (いずれも $\mathrm{mol} \%$ )
のみの低下を示す.これは前にも示したよらに陽イオン 吸着のため $\mathrm{Si}$ 添加による $\mathrm{Si}-\mathrm{O}$ 結合の増加は $E_{\mathrm{ecm}}$ には 影響はなく $\gamma_{\text {ecm }}$ のみに影響するのであろう，第 9 図(c) は $\mathrm{Pb}-\mathrm{Sn}$ 合金と $50 \mathrm{SiO}_{2}, 30 \mathrm{CaO} 20 \mathrm{Na}_{2} \mathrm{O}$ スラグの電気 毛管曲線である． $E_{\mathrm{ecm}}$ は $\mathrm{Pb}$ 含有量の増加と共に正電位 の方に移行する． $E_{\mathrm{ecm}}$ と合金組成との間には加成性が 成立っている，第 9 図(d)は Nikitin らが第 4 図の方法 によって硫化物とスラグ系に拈いてもメタルースラグ系 と同様の傾向を示すことがあきらかである.

電気毛管曲線と温度との関係についてはあまり報告は みられないが Vaniukov が先に示した $\mathrm{Pb}$ と $\mathrm{CaO}-\mathrm{Na}_{2} \mathrm{O}$ $\mathrm{SiO}_{2}$ スラグについて観察されている. その結果は形状に 大きな変化はなく温度によって $E_{\mathrm{ecm}}$ は変らず $\gamma_{\mathrm{ecm}}$ が 増加を示すのみである。

以上のようにメタルースラグ系においても電気毛管曲 線が得られることがあきらかになった. 界面張力と界面 電位の間に Lippmann の式
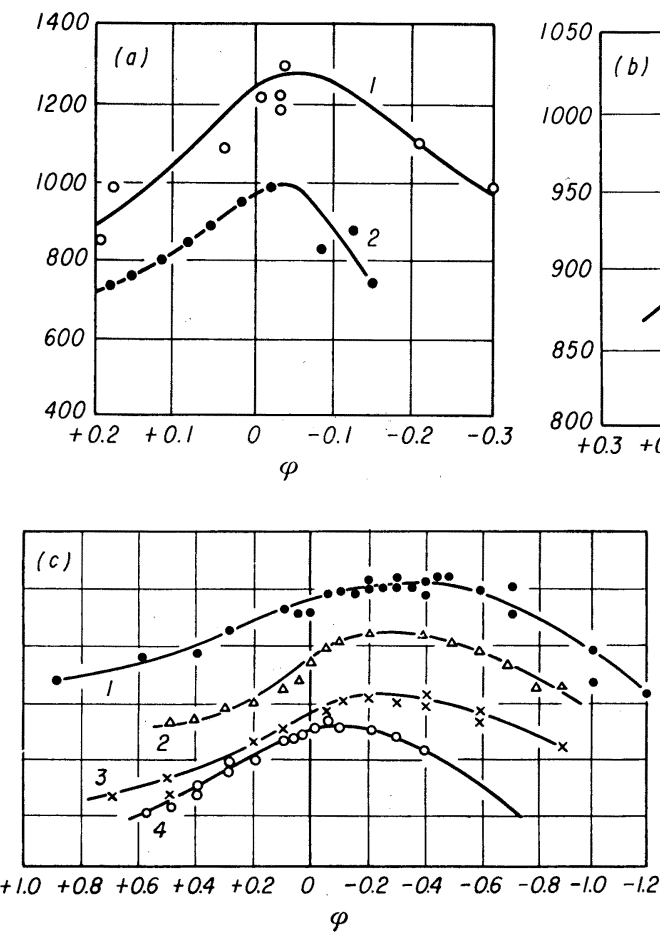
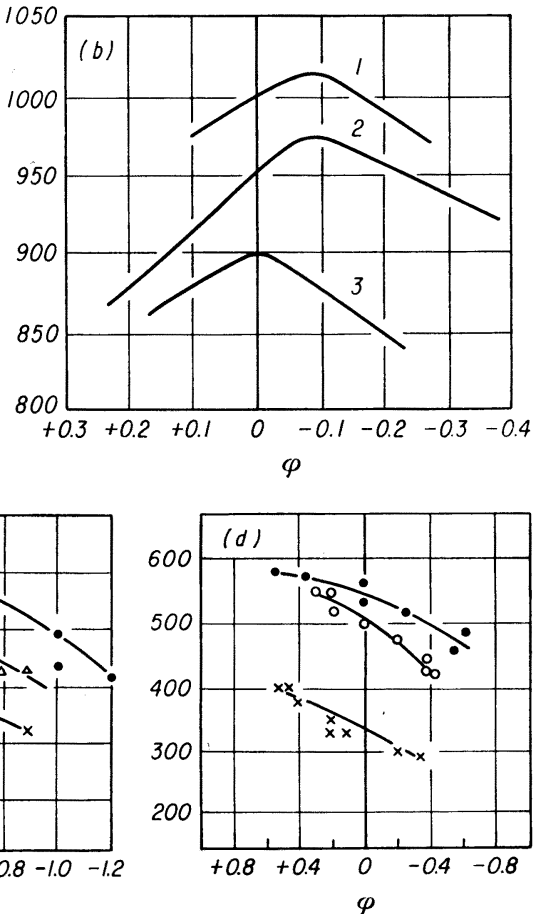

(a) $\mathrm{Cu}$ ースラグ系(4)

1 : $\mathrm{CaO} 40 \%, \mathrm{SiO}_{2} 40 \%$, $\mathrm{Al}_{2} \mathrm{O}_{3} 20 \%$

2 : $\mathrm{CaO} 55 \%, \mathrm{Al}_{2} \mathrm{O}_{3} 45 \%$

(b) 銑鉄-スラグ系 ${ }^{(5)}$

スラグ (mol\%) $41.6 \mathrm{CaO}$, $47.3 \mathrm{SiO}_{2}, 11.1 \mathrm{Al}_{2} \mathrm{O}_{3}$ メタル $(\mathrm{at} \%) 1: 14 \% \mathrm{C}$, $0.9 \% \mathrm{Si}, 2 \% \mathrm{Mn}, 0.06 \% \mathrm{~S}$ $2: 13 \% \mathrm{C}, 3.5 \% \mathrm{Si}, 0.6 \%$ $\mathrm{Mn}, 0.06 \% \mathrm{~S}$

$3: 13 \% \mathrm{C}, 3.5 \% \mathrm{Si}, 2.1 \%$ $\mathrm{Mn}, 0.06 \% \mathrm{~S}$

(c) $\mathrm{Pb}-\mathrm{Sn}$ 合金と $50 \% \mathrm{SiO}_{2}, 30$ $\% \mathrm{CaO}, 20 \% \mathrm{Na}_{2} \mathrm{O}$ スラグ 系(6) $\left(1250^{\circ} \mathrm{C}\right)$

$1: \mathrm{Sn}, \quad 2: 40 \% \mathrm{~Pb}+60 \%$ $\mathrm{Sn}, 3: 70 \% \mathrm{~Pb}+30 \% \mathrm{Sn}$, $4: \mathrm{Pb}$

(d) $\mathrm{Mn}-\mathrm{C} / 25 \% \mathrm{CaO}$, $12 \% \mathrm{Al}_{2} \mathrm{O}_{3}, 63 \% \mathrm{SiO}_{2}{ }^{(7)}$ $\mathrm{Ni}-\mathrm{S} / 14.6 \% \mathrm{Na}_{2} \mathrm{O}, 8.3 \%$ $\mathrm{CaO}, 5.6 \% \mathrm{Al}_{2} \mathrm{O}_{3}, 71.5 \%$ $\mathrm{SiO}_{2}$

$\mathrm{CuS}-/ 14.6 \% \mathrm{Na}_{2} \mathrm{O}, 8.3 \%$ $\mathrm{CaO}, 5.6 \% \mathrm{Al}_{2} \mathrm{O}_{3}, 71.5 \%$ $\mathrm{SiO}_{2}$

第 9 図 高温に拈けるメタルースラグ系の電気毛管曲線

9 図(b) は $\mathrm{Fe}-\mathrm{Mn}-\mathrm{Si}-\mathrm{C}$ 合金と $\mathrm{CaO}-\mathrm{SiO}_{2}-\mathrm{Al}_{2} \mathrm{O}_{3}$ 系スラ グにおいて Mn, Si の影響を検討した場合であって Mn， $\mathrm{Si}$ 量によって電気毛管曲線は変化する.メタル相中に $\mathrm{Mn}$ が増加すると $E_{\mathrm{ecm}}$ は正電位側に移行し $\gamma_{\mathrm{ecm}}$ は低下 する.これは $\mathrm{Mn} か ゙ \mathrm{Mn}^{2+}$ としてスラグ側に移行するた めと考えられる $\mathrm{Si}$ の影響は $E_{\mathrm{ecm}}$ にはあらわれず, $\gamma_{\mathrm{ecm}}$

(5) B.V.Patrov : Izvest. VUZ. Chern. Met., (1962), No.1, 45.

$$
\gamma_{\mathrm{ecm}}-\gamma=\frac{C}{2}\left(\varphi_{\mathrm{ecm}}{ }^{2}-\varphi^{2}\right)
$$

が成立するものとすれば表面電荷密度, 電気二重層容量 を計算することができる。

(6) A.V.Vaniukov, I.I.Kirillin and V.la.Zaichev: Izvest.VUZ. Tsvet.Met., (1970), No.4, 38.

(7) Iu.P. Nikitin and O.A.Esin : Doklad. Akad. Nauk.SSSR, $107(1956)$, No.6, 847. 
$-(\partial \gamma / \partial \varphi)=C \cdot \varphi=Q$

（表面電荷密度）

$-\left(\partial^{2} r / \partial \varphi^{2}\right)=-(\partial Q / \partial \varphi)=C$ (電気二重層容量) $(3)$ メタルースラグ系の電気毛管曲線は第 5 図, 第 7 第 9 図にみるように電位に対して $r_{\mathrm{m} \cdot \mathrm{s}}$ はほぼ 2 次曲線ある いはその一部分を示しているとみられる。 その結果, $\gamma$ と $\varphi$ の間に Lippmannの式が成立つとして (2),(3)式 より表面電荷密度, 電気二重層容量を計算することがで きる。

\section{（2）表面電荷密度}

前述のようにメタルースラグ系においては電気毛管現 象が観察され，電気毛管曲線が得られた。このことはメ タル側およびスラグ側にそれぞれ相反する電荷が帯電し 界面電気二重層が形成されることである. その結果同種 イオン間にはお互いに哌力が働き界面を抎大しょうとす る傾向が生じる.この傾向はメタル表面の電荷密度の大 きい程大きい，したがって表面張力は小さくなる．この 斥力は電荷の積に比例するから $\gamma$ と電荷密度 $\varepsilon$ との間に は $\sim \varepsilon^{2}$ の関係が成立つ.

この表面電荷密度は前述の電気毛管曲線から計算によ って求められ，また直接測定も可能である．この直接测 定は Nikitin ら (7)によって 1956 年になされている.そ の方法は第 10 図に示すような滴下電極法を模した装置 を用い,メタル室 6 , 内のメタルを一滴だけ細管 3 を通 じてスラグ室 5 内に押し出し，そのとき 1,2 間に流れる 電流を電流計 $\mathrm{G} て ゙$ 測定するもので, 滴の形状と電気量と から表面電荷密度を求めている. この方法によって Fe$\mathrm{C}_{\text {sat }}$ 合金と $39 \% \mathrm{CaO}, 40 \% \mathrm{SiO}_{2}, 20 \% \mathrm{Al}_{2} \mathrm{O}_{3}$ スラグに拈
ける表面電荷密度として $3 \times 10^{-6}$ coulomb $/ \mathrm{cm}^{2}$ を得て いる。 また $\mathrm{Mn}-\mathrm{C}_{\text {sat }}$ 合金と $25 \% \mathrm{CaO}, 63 \% \mathrm{SiO}_{2}, 12 \%$ $\mathrm{Al}_{2} \mathrm{O}_{3}$ スラグとの場合には $6 \times 10^{-6}$ coulomb $/ \mathrm{cm}^{2}$ が得ら れている.このように直接測定からは $10^{-6}$ coulomb $/ \mathrm{cm}^{2}$ の order の值が得られているが，それ以後直接測定がな されていないので比較は電気毛管曲線より求める間接法 とについてなされる。

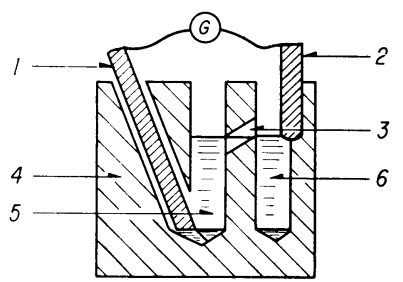

第 10 図 メタルースラグ界面の電荷密度測定装 置 ${ }^{(7)}$

1,2:黒鉛極, $3:$ 毛管, $4:$ マグネシヤ ルツボ, $5:$ スラグ室, $6:$ メル室

直接, 間接法によって得られた種々な系の表面電荷密 度の值を第 1 表に総括する．表より表面電荷密度は直接 測定值に近いものもあるが，1桁大きいものも多々みら れる.この電荷密度はメタルおよびスラグ組成によって 変化し， $E_{\mathrm{ecm}}$ より正の電位の領域ではスラグ組成中塩 基性酸化物の増加と共に増加するのがみられる。これは $\mathrm{Ca}^{2+}$ イオンの増加によるものである. 一方負の電荷領 域ではほとんど变化せず一定である．著者ら ${ }^{(8)}$ の值は炭 素飽和溶鉄と $\mathrm{CaO}-\mathrm{SiO}_{2}-\mathrm{Al}_{2} \mathrm{O}_{3}$ 系スラグ間の界面張力が スラグ中に含まれる少量の鉄イオンの量によって変化す

第 1 表 種々なメタルースラグ系の表面電荷密度

\begin{tabular}{|c|c|c|c|c|}
\hline メ タ ル & グ & $\mid \begin{array}{c}\varepsilon \times 10^{6} \\
\left(\text { coulomb } / \mathrm{cm}^{2}\right)\end{array}$ & 備 & 文 献 \\
\hline $\begin{array}{l}\mathrm{Fe}-\mathrm{C}(2.5 \%) \\
\mathrm{Fe}-\mathrm{C}(3.0 \%) \\
\mathrm{Fe}-\mathrm{C}(4.0 \%)\end{array}$ & $\begin{array}{l}8.3 \% \mathrm{CaO}_{1} 14.6 \% \mathrm{Na}_{2} \mathrm{O}, 71.5 \% \mathrm{SiO}_{2} \\
5.6 \% \mathrm{Al}_{2} \mathrm{O}_{3}\end{array}$ & $\begin{array}{l}50 \\
45 \\
30\end{array}$ & $\begin{array}{l}\text { 電気毛管曲線法 } \\
\text { 負 電 位 領 域 }\end{array}$ & 1 \\
\hline $\begin{array}{l}\mathrm{Fe}-\mathrm{C}(3.1 \%) \\
\mathrm{Mn}-\mathrm{C}(6.9 \%)\end{array}$ & $\begin{array}{l}39 \% \mathrm{CaO}, 41 \% \mathrm{SiO}_{2}, 20 \% \mathrm{Al}_{2} \mathrm{O}_{3} \\
25 \% \mathrm{CaO}, 63 \% \mathrm{SiO}_{2}, 12 \% \mathrm{Al}_{2} \mathrm{O}_{3}\end{array}$ & $\begin{array}{l}3 \\
6\end{array}$ & 充 電 電 流 法 & 7 \\
\hline $\mathrm{Fe}-\mathrm{C}-\mathrm{Mn}-\mathrm{Si}$ & $37 \sim 45 \% \mathrm{CaO}, 45 \sim 37 \% \mathrm{SiO}_{2}-18 \% \mathrm{Al}_{2} \mathrm{O}_{3}$ & $33 \stackrel{16}{2} 85$ & $\begin{array}{l}\text { 電気毛管曲線法 } \\
\text { 負電位領域, 正電位領域 }\end{array}$ & 3 \\
\hline $\begin{array}{l}\mathrm{Fe}-\mathrm{C}-\mathrm{Mn}-\mathrm{Si} \\
\mathrm{Mn}(0.6 \sim 30 \text { at } \%) \\
\mathrm{Si}(0.9 \sim 3.5 \text { at } \%)\end{array}$ & $37 \% \mathrm{CaO}, 45 \% \mathrm{SiO}_{2}, 18 \% \mathrm{Al}_{2} \mathrm{O}_{3}$ & $16 \sim 26$ & $\begin{array}{l}\text { 電気毛管曲線法 } \\
\text { 負 電 位 領 域 }\end{array}$ & 5 \\
\hline $\mathrm{Pb}$ & $20 \% \mathrm{CaO}, 50 \% \mathrm{SiO}_{2}, 20 \% \mathrm{Al}_{2} \mathrm{O}_{3}$ & $2 \sim 14$ & $\begin{array}{l}\text { 電気毛管曲線法 } \\
\text { 電 位 領 域 }\end{array}$ & 6 \\
\hline $\mathrm{Fe}-\mathrm{C}$ & $45 \% \mathrm{CaO}, 40 \% \mathrm{SiO}_{2}, 15 \% \mathrm{Al}_{2} \mathrm{O}_{3}$ & $1.3 \sim 1.6$ & $\begin{array}{l}\text { 電気毛管曲線法 } \\
\text { (界面張力測定値より仮定 } \\
\text { 負の電位領域) }\end{array}$ & 8 \\
\hline
\end{tabular}

（8）荻野和巳, 原 茂太, 足立 彰, 桑田 寛: 鉄と 鋼, 59(1973), 28. 
ることから, 種々の仮定のもとでこの系の電気毛管曲線 を求め, それより界面電荷密度を計算したものである. その場合炭素飽和溶鉄とスラグとが平衡していると界面 には $1.3 \sim 1.6 \times 10^{-6} \mathrm{coulomb} / \mathrm{cm}^{2}$ 程度の過唾電荷が存 在し, 界面には $8 \times 10^{-10} \mathrm{~g}$-ion $/ \mathrm{cm}^{2}$ 程度の $\mathrm{Fe}^{2+}$ イオン の吸着のあることが予測された。

\section{（3）界面電気二重層とその性質}

前述の界面電気現象の存在からもあきらかなようにメ タルースラグ界面には界面電気二重層の存在が確認され ている．この界面電気二重層はメタルースラグ間の電極 反応やスラグーメタル・エマルジョン，あるいは銅製錬 に打けるスラグロス，さらに ESR 法, ESW 法における 界面での発熱の問題のように界面の関係する多くの過程 において大きな役割をはたしているといわれる.

\section{(i) 界面電気二重層の構造 ${ }^{(9)}$}

界面電気二重層の構造は電気毛管現象のほかに, 電 極 - 溶液間の界面インピーダンスや界面に直流分極を加 えた場合の過渡現象の測定から知ることがでさる。これ らを基にして古くから構造については種々な説が示され ている.

最も古い電気二重層のモデルは 1879 年 Helmholtz が 提示した平板コンデンサーモデルである. これは電極 溶液の界面を単位面積あたりCを持つコンデンサーとみ なすものであり, この場合コンデンサーには漏洩電流を 考えていないので，このモデルは理想分極性の界面にの み限定される.

Gouy-Chapman はイオンの熱運動を考慮して溶液 側の電荷の分布を拡散的と考えて拡散二重層モデルを 1910 年に示した. この説は Helmholtz の平板コンデン サー説より事実に近いと考えられるが, 実験結果との比 較において希薄溶液でしかも電気毛管極大点近くにおい てのみ理論值と実験值が一致するにすぎない. Sternは 1924 年電気二重層として電極近くでは Helmholtz 二重 層があり，その外側に拡散二重層が存在するモデルを考 えた。このモデルは微分容量からは立証されないが界面 に特異吸着層が考慮されている. Graham は 1946 年, 電極面に和水しないアニオンが特異吸着する面として内 部ヘルムホルツ面と, 和水しないカチオンおよび和水し たイオンの最接近面として外部へルムホルツ面を考え， その外側には拡散二重層が存在するモデルを示した。こ の Graham のモデルによって電極 - 溶液の界面におけ るイオンの界面電気二重層の体系はほぼ完成されたとさ れている.

このように界面電気二重層に対して種々な説が示され

（9）外島：基礎電気化学, 朝倉書店, (1965).

(10) Yu.P.Nikitin and O.A.Esin : Doklad.Akad. Nauk.SSSR, 111 (1956), 133.

(11) Yu.P.Nikitin and O.A.Esin : Doklad.Akad. Nauk.SSSR, 116(1957), 63.
ているが，メタルースラグ界面においてはどのように考 えればよいであろらか。これに先立って界面構造に対す る有力な手掛りである界面二重層の性質に関する知識を まとめてみよう。

\section{(ii) 界面電気二重属の容量}

メタルースラグ界面の電気二重層の容量に関する測定 は困難が多いために報告は少なく，かつ十分に統一した 見解が得られていない. 測定方法としては (a) 交流ブリ ッヂ法, (b) パルス法, (c) 電気毛管曲線より求める方法 がある。

交流ブリッヂ法はインピーダンスブリッヂを用いて界 面容量を測定するもので電解質水溶液に対して多く用い られている方法である。本法をメタルースラグ間の界面 容量の測定に適用したのは Esin ら (10)が最初である.こ の装置ならびにそれ以後メタルースラグ界面の二重層容 量の測定に用いた種々なセルをまとめて第11 図に示す. (a)

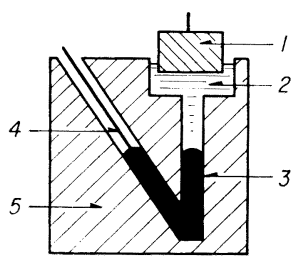

(c)

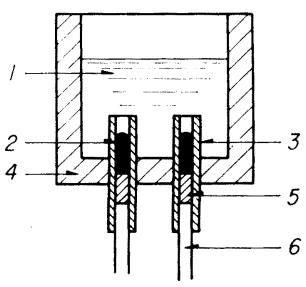

(b)

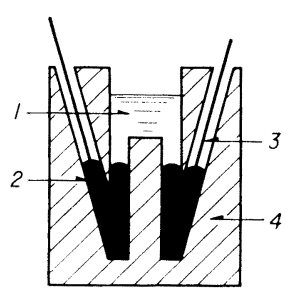

(d)

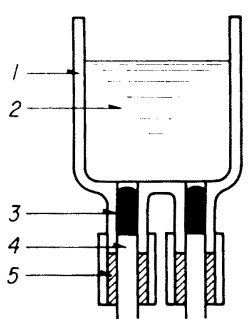

第 11 図メタルースラグ界面電気二重層容量測定用セル (a) Nikitin, Esin ${ }^{(10)}$

1 : 黒鉛極, $2:$ スラグ, $3:$ タル極 4 : サード, 5 : マグネシャルッボ

(b) Nikitin, Esin(11)(12) 1 : スラグ, 2 : メタル極, 3 : リー ド, 4 : マグネシヤルツボ

(c) Esin, Sotnikov, Nikitin (13) 1 : スラグ, 2 : メタル電極, 3 : ア ルミナ毛細管, 4 : 黑鉛ルツボ, 5 : 黒鉛, 6:タングステン

(d) Adach, Ogino, Hara(14) 1 : アルミナルツボ, 2 : スラグ 3 : メタル電極, 4 : Mo, 5 : アルミ ナセメント

(12) Yu.P.Nikitin and O.A.Esin : Nauch.Doklad. B.Sh.Met., (1958), No.1.

(13) O.A.Esin. A.I.Sotnikov and Yu.P. Nikitin : Doklad.Akad.Nauk.SSSR, 158(1964), 1149.

(14) A.Adachi.K.Ogino and S.Hara : Tech.Repts. Osaka Univ., 21 (1971), 427. 
パルス法は一定波形のパルスを定電位的あるいは定電流 的に印加し，パルスに対する電流または電位の応答を観

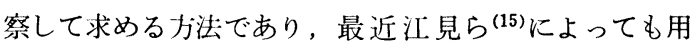
いられている．間接的に電気毛管曲線より求める方法は Esin ら ${ }^{(16)}$, Patrov ${ }^{(4)(6)}$ によって報告されている.

以上のようにメタルースラグ系に㨟いて直接あるいは 間接的に測定がなされているが，それらの結果について まとめてみる。第 12 図はEsin らが第 11 図(a)の装置 によって求めた印加電圧と界面容量の関係であり，これ からもあきらかなように界面容量は印加電圧が 0.2 $-0.2 \mathrm{~V}$ の電位の範用ではほとんど変化せず, Fe のス ラグへの溶解, $\mathrm{Si}, \mathrm{Al}$ の放電電位になると容量の増加す るのがみられる。Esin ら(17)が第 11 図(b)のセルを用い 種々な金属, 合金, 硫化物とスラグ系との界面電気二重 層の容量を求めているがこれを第 2 表にまとめて示す.

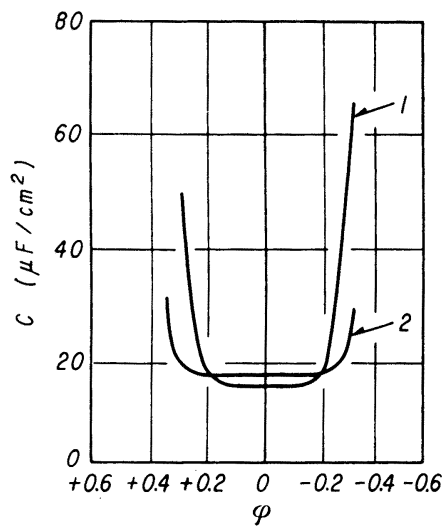

第 12 図 メタルースラグ界面の電気二重層容量 ${ }^{(11)}$

$1: \mathrm{Fe}-\mathrm{C}_{\text {sat }} / \mathrm{CaO}-\mathrm{SiO}_{2}-\mathrm{Al}_{2} \mathrm{O}_{3}$

$2: \mathrm{Mn}-\mathrm{C}_{\text {sat }} / \mathrm{CaO}-\mathrm{SiO}_{2}-\mathrm{Al}_{2} \mathrm{O}_{3}$

第 2 表 メタルースラグ界面の電気二重層容量 ${ }^{(17)}$

(a)メタル組成と容量

\begin{tabular}{|c|c|c|c|c|}
\hline \multirow{2}{*}{ メタル組成 } & \multicolumn{3}{|c|}{ スラグ組成 $(\%)$} & \multirow{2}{*}{$\underset{\left(\mu \mathrm{F} / \mathrm{cm}^{2}\right)}{C}$} \\
\hline & $\mathrm{CaO}$ & $\mathrm{SiO}_{2}$ & $\mathrm{Al}_{2} \mathrm{O}_{3}$ & \\
\hline $\begin{array}{l}\mathrm{Fe}-4.5 \% \mathrm{C} \\
\mathrm{Fe}-44.6 \% \mathrm{Si} \\
\mathrm{Fe}-19.8 \% \mathrm{P} \\
\mathrm{Mn}-6.9 \% \mathrm{C}\end{array}$ & $\begin{array}{l}43.5 \\
40.0 \\
40.0 \\
42.5\end{array}$ & $\begin{array}{l}42.5 \\
39.0 \\
39.0 \\
42.5\end{array}$ & $\begin{array}{l}15 \\
21 \\
21 \\
15\end{array}$ & $\begin{array}{l}14.3 \\
14.9 \\
14.4 \\
14.8\end{array}$ \\
\hline
\end{tabular}

(b) スラグ組成と容量

\begin{tabular}{c|c|c|c}
\hline \hline メタル組成 & スラ グ 組 成 $(\%)$ & $C\left(\mu \mathrm{F} / \mathrm{cm}^{2}\right)$ \\
\hline $\mathrm{Fe}-4.5 \% \mathrm{C}$ & $\mathrm{MgO} 26.3 \mathrm{SiO}_{2} 49.5 \mathrm{Al}_{2} \mathrm{O}_{3} 24.2$ & 21.8 \\
& $\mathrm{CaO} 42.5 \mathrm{SiO}_{2} 42.5 \mathrm{Al}_{2} \mathrm{O}_{3} 15$ & 14.3 \\
& $\mathrm{BaO} 42.5 \mathrm{SiO}_{2} 47.8 \mathrm{Al}_{2} \mathrm{O}_{3} 10$ & 10.7 \\
& $\mathrm{Na}_{2} \mathrm{O} 5 \mathrm{SiO} \mathrm{SiO}_{2} 49$ & 15.9 \\
& $\mathrm{Na}_{2} \mathrm{O} 40 \mathrm{~B}_{2} \mathrm{O}_{3} 60$ & 15.5 \\
& $\mathrm{CaO} 55 \mathrm{SiO}_{2} 45$ & 14.7 \\
& $\mathrm{CaO} 50 \mathrm{Al}_{2} \mathrm{O}_{3} 50$ & 14.9 \\
\hline
\end{tabular}

(15) 江見俊彦, 桜谷敏和：金属学会シンポジウム講演 予稿, (1972.10), 77 .
表から界面容量は電極の成分によって大きな影響をうけ ないことがあきらかである．しかし界面活性元素である $\mathrm{S}$ をタルに添加すると界面容量は増加する(13)(14). こ れはメタルースラグ間に分配された S が $\mathrm{O}^{2-}$ イオンと置 換してスラグ中に入るが， $\mathrm{O}^{2-}$ イオンとは異なって $\mathrm{Si}^{4+}$ と珪酸アニオンを作らず二重層を破壊する結果と考えら れる。

スラグ組成の影響は第 2 表に示すが，この表からスラ グ中の陽イオンの種類によって界面容量は変化し $\mathrm{Ba}^{2+} \rightarrow$ $\mathrm{Ca}^{2+} \rightarrow \mathrm{Mg}^{2+}$ の順に大きくなっていくことを示している. さらに第13 図に示すように $\mathrm{CaO}-\mathrm{Al}_{2} \mathrm{O}_{3}$ 系に $\mathrm{SiO}_{2}$ が添 加されると界面容量は大きく低下するのがみられるが, これは $\mathrm{SiO}_{2}$ の添加によって生じた $\mathrm{Si}-\mathrm{Al}-\mathrm{O}$ アニオンの ために二重層の厚さが増加し, そのために容量が減じる と解釈されている.

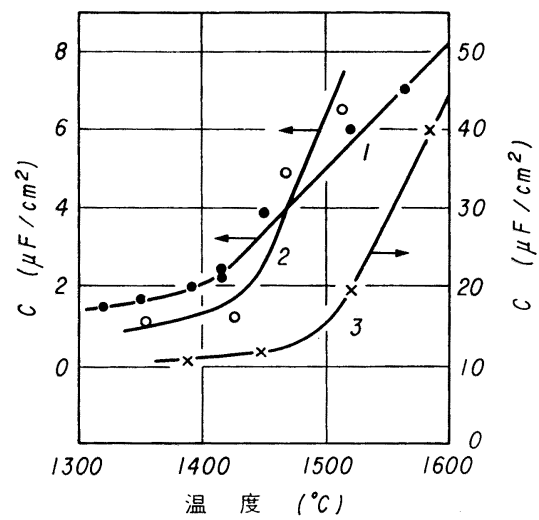

第 13 図 溶鉄-スラグ間の界面容量と温度の関係 ${ }^{(13)}$ $1: 40 \% \mathrm{CaO}, 40 \% \mathrm{SiO}_{2}, 20 \% \mathrm{Al}_{2} \mathrm{O}_{3}$
$2: 52 \% \mathrm{CaO}, 41 \% \mathrm{SiO}_{2}, 7 \% \mathrm{Al}_{2} \mathrm{O}_{3}$
$3: 47 \% \mathrm{CaO}, 53 \% \mathrm{Al}_{2} \mathrm{O}_{3}$

メタルースラグ界面の構造は両相組成のほか, 温度に よっても影響をらける，Esin らは交流ブッッヂを用い て $\mathrm{Fe}-\mathrm{C}_{\text {sat }}$ 合金と $\mathrm{CaO}-\mathrm{SiO}_{2}-\mathrm{Al}_{2} \mathrm{O}_{3}$ スラグの界面容量を $1300 \sim 1600^{\circ} \mathrm{C}$ の温度領域で測定した，それによると第 13 図に示すよらに電気二重層容量は温度の上昇と共に 増大する.この傾向は温度の上昇に伴って容量の減少 する水溶液と異なり, 溶融塩中の挙動と類似している. この挙動はスラグ中に形成される電気二重層が多層であ り，その有効厚さが温度の上昇と共に減じることに起因 すると考えている.

一方, 溶融メタルースラグ界面ではなく固体電極(黒 鉛，Pt)/スラグ界面においても電気二重層に関する報告

(16) O.A. Esin and Yu.P. Nikitin : Fiz.-Khim. Osnov.Proiz-va,Stal., (1957), 446.

(17) Yu.P. Nikitin and O.A.Esin : Izvest. VUZ. Chern.Met., (1959), No.9, 3. 
がみられる. 最近 Kukhtin ら ${ }^{(18)} は \mathrm{CaO}-\mathrm{SiO}_{2}-\mathrm{Al}_{2} \mathrm{O}_{3}$ 系, $\mathrm{CaO}-\mathrm{Al}_{2} \mathrm{O}_{3}-\mathrm{MgO}$ 系スラグ中に扮かれた炭素質電極面上 での CO ガス生成の電気化学プロセスの研究を早い電極 反応速度研究のための 緩和法の一つである Galvanostep 法を用いて解析している。，その際測定される非フォラデ 一電流から電極界面での電気二重層容量を求めている. 得られた界面二重層容量は電極として用いる炭素質電極 材料の種類によって若干異なるが，いずれの場合も温度 之共に上昇し数 $\mu \mathrm{F} / \mathrm{cm}^{2}\left(1350^{\circ} \mathrm{C}\right)$ から数十 $\mu \mathrm{F} / \mathrm{cm}^{2}(1550$ $\left.{ }^{\circ} \mathrm{C}\right)$ の值をとる.これらの值は前述の交流分極法による 值と良好な一致がみられる，我国においても交流分極

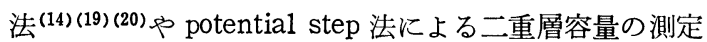
がなされている.これらの結果は測定者によって数 $\mu$ $\mathrm{F} / \mathrm{cm}^{2}$ から数百 $\mu \mathrm{F} / \mathrm{cm}^{2}$ にまで著しい相違がみられる.

高温でのメタル(固体または液体)ースラグ間の電気二 重層容量の測定に当っては交流分極法では拡散容量の寄 与の分離(高温系では拡散容量は著しく大きい)を正しく 行ならことが必要であり，また直流分極による非定常法 (potential step, Galvano step 法など) では電極反応速 度の速さによっては(メタルースラグ系では高温のため 電極反応速度は相当速いことが予想される)二重層容量 の充電電流と反応電流との分離が困難な場合も考えられ る. このようにメタルースラグ界面に打ける界面電気二 重層の形成については明らかになったと考えられるが， その構成については，二重層の容量そのものがすでに大 きな相違を有しているため現在種々な見解が提示されて いる段階である．今後高温に佂けるメタルースラグ系の 二重層容量の測定法の確立をまってさらにこの分野の見 解が整理されるであろう。

\section{3. スラグ -メタル間の界面現象と界面電気現象}

メタルースラグ界面には種々な界面現象がみられ る(21)。例㓪ばメタルースラグ間の界面エネルギーや付 着の問題, メタルースラグ・エマルジョンの問題, ある いはスラグ中のメタル滴の電気毛管運動など，これらの 現象はメタルとスラグの分離, 介在物の除去, スラグロ スなど実際操業における諸現象の解明にとってきわめて 重要である。これらの界面現象はメタルースラグ間の界 面構造と密接に結びついているから，前述の界面電気現 象と関連が深い。

メタルースラグ間の界面張力 $\gamma_{\mathrm{sm}}$ や付着の仕事 $W_{\mathrm{sm}}$ は界面に批活両相構成粒子間に働くVan der Waals カによる化学結合と界面二重層中の過㮃電荷の静電的相 互作用によってきまってくる，そのため $\gamma_{\mathrm{sm}}, W_{\mathrm{sm}}$ の変

(18) B.A.Kukhtin et al. : Izvest.VUZ. Chern. Met., (1969), No.8, 19.

(19) 籠橋 亘, 後藤和弘：鉄々鋼，59(1973)，63.

(20) 芦塚正博, 志垣和博: 金属学会春期講演概要, (1972.4).
化は化学結合と電荷密度によってきまってくる．電荷の 影響は前述の電気毛管曲線によって求めらるから電気毛 管曲線の観察が重要となってくる. 電気毛管曲線の $E_{\mathrm{ecm}}$ においては $\gamma_{\mathrm{sm}}$ は最大であり,この点においてはとは 0 である。 そのため界面張力は相互作用のみによってあら われる. $\gamma_{\mathrm{sm}}$ のメタルの電極電位による減少は静電的な 相互作用が強まるために生じるのであるう。

Deriavin ら ${ }^{(22)}$ はメタルースラグ間の界面張力への電 位の効果の研究加界面張力几与える電気化学的効果に ついて論じている，それによるとメタルースラグ界面に おいて吸着のある場合 Lippmann の式

$d \gamma_{12}=-\varepsilon \cdot d \varphi$ ではなく(4)式によって示される.

$$
d \gamma_{12}=-\left[\varepsilon+F \sum_{i=1}^{k} n_{i} \cdot \Gamma_{i}\right] d \varphi-\sum_{j=k+1}^{m} \Gamma_{j} \cdot d \mu_{j}
$$

ただし $m$ :系中の成分の全数, $k:$ ポテンシャルによって 変化する平衡の数, $\left(\Gamma_{i}\right)_{\mathrm{m}}$ : メタル側の吸着量, $\left(\Gamma_{i}\right)_{\mathrm{el} .}$ ： 電解質溶液側の吸着量, $\Gamma_{i}=\left(\Gamma_{i}\right)_{\mathrm{m}}+\left(\Gamma_{i}\right)_{\mathrm{el}}$.

このような系における電位による界面張力の変化量は 両相の境における濃度変化と電荷密度の増加によって生 じる変化の総和である。

$$
\Delta \gamma_{12}=\Delta \gamma_{\mathrm{el} .}+\Delta \gamma_{\text {conc }}
$$

メタルースラグ間の界面張力の变化と電気毛管曲線の 形状との関係は溶融塩と違って分極のさいに二重層中の 過剩電荷の蓄積が十分明らかでないために不明瞭であ る.メタルースラグ界面における二重層容量は数 $\mu \mathrm{F} /$ $\mathrm{cm}^{2}$ であり，メタル組成には関係が少ないが，スラグ組 成には影響をうける。ささらに二重層容量は電位によって 大きく変化しない，とすると電荷密度が変化しても界面 張力への影響は小さい. 実際この効果を求めてみると, いま $\mathrm{Fe}-\mathrm{C}_{\mathrm{sat}}$ 合金とスラグ系において $\Delta \gamma_{\mathrm{el} .}=5 C(\Delta \varphi)^{2}$ なる関係が得られているが，この関係を用いてアノード 分極 $\Delta \varphi=0.5 \mathrm{~V}$ では $\Delta \gamma_{\mathrm{el}}=2.5 \mathrm{dyne} / \mathrm{cm}$ で界面張力 の全変化量の $2 \%$ にすぎない. $\Delta \varphi=0.3 \mathrm{~V}$ では $\Delta \gamma_{\mathrm{el}}$. $=0.9 \mathrm{dyne} / \mathrm{cm}$ で $1 \%$ である. このようにメタル $(\mathrm{Fe}-$ $\mathrm{C}$ 合金) とスラグとの界面張力への電位の効果は電極近 傍に扣忛るスラグ組成の变化に密接に関連することが明 らかである。

以上のことから高温では化学反応の速度がはやいため に拡散による効果が大きく界面構造に影響していると考 えられる。このことは界面張力が化学反応の進行する場

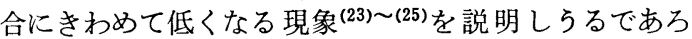
万.

（21）荻野和巳：金属学会会報, 11(1972)，323.

(22) A.A.Deriavin and L.N.Saburov : Paverkhnostnye Javlenija $v$ Rasplavakh, Nukova Dumka, (1968) , 306.

(23) A. A. Deriabin, et al. : Izvest. Akad. Nauk. SSSR, Metal.,(1968), No.5, 51.

(24) 大井 浩, 野崎 努, 吉井 裕 : 鉄と鋼, 58 $(1972), 830$. 
銅製鍊においては銅マットがスラグ中にとらえられ銅 の損失になるいわゆるスラグロスなる現象があり, 0.3 〜0.8\%の の $\mathrm{Cu}$ が失われるといわれる. このようにスラ グ中にマットがとらえられる機構として一般に物理的に スラグ表面に浮いたり，スラグ中に小さな液滴となって 稣濁するか，あるいは化学的に溶解するかが考えられて いる.

一方，酸素製鋼プロセスにおいてはスラグ中に鋼粒滴 がェマルジョン状に存在し製鋼反応の進行に大きな役割 をはたすといわれている．このエマルジョンはいわゆる エマルジョンの定義からみるとサイズでは一致しない が，エマルジョンの特殊な形体と考えることができる.

このよらにスラグ中にメタルもしくは金属化合物が小 さな液滴としてェマルジョン状態に移行する機構として は反応に伴って発生する気泡の破裂に関連するとされて いる.これは気泡の表面を覆っているメタルやマットの 被膜が気泡破裂によって小滴として分散するのである. スラグ中に分散された小さい融体滴はスラグがイオン性 溶液であるため, その界面には当然界面二重層が形成さ れるであろら。とするとスラグ中に拈いて融体滴には電

第 3 表 $52 \% \mathrm{CaO}, 41 \% \mathrm{Al}_{2} \mathrm{O}_{3}, 7 \% \mathrm{SiO}_{2}$ スラグ中の 電気毛管運動(11)

\begin{tabular}{c|c|c|c|c|c}
\hline \hline 粒 滴 & $\begin{array}{c}E \\
(\mathrm{~V} / \mathrm{cm})\end{array}$ & $r(\mathrm{~cm})$ & $\begin{array}{c}U \\
(\mathrm{~cm} / \mathrm{sec})\end{array}$ & $\begin{array}{c}v \\
(\mathrm{~cm} / \mathrm{sec} \cdot \mathrm{V})\end{array}$ & $\begin{array}{c}\text { 運動の } \\
\text { 向 }\end{array}$ \\
\hline $\mathrm{Cu}$ & 2.3 & 0.07 & 5.8 & 36 & 陰極へ \\
$\mathrm{Ni}$ & 2.0 & 0.05 & 2.8 & 28 & "' \\
$\mathrm{Mn}$ & 2.8 & 0.075 & 6.3 & 30 & "' \\
$\mathrm{Ni}_{3} \mathrm{~S}_{2}$ & 2.3 & 0.05 & 4.8 & 42 & 陽極へ \\
$\mathrm{Ni}_{3} \mathrm{~S}_{2}$ & 6.6 & 0.025 & 7.5 & 46 & "' \\
$\mathrm{Ni}_{3} \mathrm{~S}_{2}$ & 6.6 & 0.05 & 15 & 46 & $\prime \prime$ \\
$\mathrm{Ni}_{3} \mathrm{~S}_{2}$ & 6.6 & 0.075 & 15 & 30 & $\prime \prime$ \\
$\mathrm{Ni}_{3} \mathrm{~S}_{2}$ & 6.6 & 0.16 & 6 & 5.7 & $\prime \prime$ \\
\hline
\end{tabular}

(25) K.Ogino and S.Hara : 第 3 回 E.S.R. 国際シン ポジウム, (1973.6).

(26) V.V.Khlynov and O.A.Esin : Doklad.Akad. Nauk.SSSR, 120(1958), 134.
解質水溶液中の水銀のように電位によってその運動に影 響をらけるいわゆる電気毛管運動が存在するであろう.

スラグ中のメタル滴に㧊いても電気毛管運動の存在す ることが Khlynov, Esin(26)によって 1958 年に実験的に 認められた. その結果を示すと第3表のようにメタルや 硫化銅の種々なサイズの滴が一定電位内で運動する場合 の速度が求められている.この速度は次の FrumkinLerich の式に諸数值を入れて求めてある.

$$
\begin{aligned}
& u=\frac{\varepsilon E r}{2 \eta+3 ? \cdot-\varepsilon^{2} / x} \\
& E \ll \varepsilon / C
\end{aligned}
$$

ここに

$u:$ 粒子の速度, $\eta, \eta^{\prime}:$ スラグとメタルの粘度, $x$ : 電気伝導度, $\varepsilon:$ 二重層の電荷, $C:$ 二重層の容量, $r:$ 粒子の径, $E:$ 電位

この理論值と実測値を比較するとき, 滴の寸法が 0.05 $\mathrm{mm}$ 以下では両者の間に良好な一致がみられるといわれ 電気毛管運動の存在が認められた。

\section{4. と め}

溶融金属と溶融スラグ間の界面現象の解明には，その 界面の性質, 構造に関する知識が必要であるが, 現在で はこの分野について得られる情報は多くはなく, 統一さ れた結果は少ない. 特に溶融スラグがイオン性溶液であ るため界面に電気現象が生じるがこの分野についての情 報はきわめて少ない.そのためより広く深い研究が期待 されるが, 特に界面構造に関して強い手掛りとなる電気 化学的なアプローチが今後益々必要と考えられる. 本解 説はメタルースラグ界面に関する電気現象の研究につい てまとめそれと界面現象との結びつきを試みたが，界面 現象の理解ならびに界面性質の研究にあたっていささか でもお役に立てば著者たちの幸せとするところである。

(1973 年 7 月 11 日受理) 